\title{
Service quality of Islamic banks: satisfaction, loyalty and the mediating role of trust
}

\author{
Razali Haron and Noradilah Abdul Subar \\ IIUM Institute of Islamic Banking and Finance, \\ International Islamic University Malaysia, Kuala Lumpur, Malaysia, and \\ Khairunisah Ibrahim \\ Department of Finance, International Islamic University Malaysia, \\ Kuala Lumpur, Malaysia
}

Service quality of Islamic banks

Received 25 December 2019 Revised 27 April 2020 Accepted 18 May 2020

\begin{abstract}
Purpose - The objective of this study is to examine the impact of PAKSERV model on customers' satisfaction, loyalty and trust in Malaysian Islamic banks. These comprehensive measures concern on the cultural dimension of service quality by focusing on the mediating role of trust in the Malaysian context.

Design/methodology/approach - A survey was conducted involving 401 customers of Islamic banks in the states of Kuala Lumpur and Selangor, Malaysia. The data were analyzed through exploratory factor analysis, confirmatory factor analysis and structural equation model employing AMOS 23 and SPSS 23.

Findings - The study found positive relationship of PAKSERV dimensions of service quality, customers' satisfaction, customers' loyalty and the mediating role of trust in enhancing customers' loyalty. This study provides new evidence on how trust can act as a partial mediation on the relationship between customers' satisfaction and customers' loyalty in the cultural context of Islamic banking in Malaysia.

Practical implications - The findings of this study can be used as a framework for other Islamic Financial Institutions (IFIs) in improving services to its customers.

Originality/value - This study contributes to the body of knowledge in enhancing the understanding on customers' satisfaction, loyalty and trust in Islamic banks in Malaysia. This study also covers a broad range of respondents, hence representing a good diversity of Islamic banks' customers.
\end{abstract}

Keywords Service quality, Satisfaction, Loyalty, PAKSERV, Islamic bank

Paper type Research paper

\section{Background and objectives of the study}

Islamic banking is a banking structure that complies with Islamic principles (Shariah) that forbid interest (ribā), gambling (maisir) and speculative trading (gharar) (Bank Negara Malaysia, 2018). In order for Islamic banks to gain competitive advantage, the banks need to improve and sustain superior service quality, meet customers satisfaction and achieve customers' loyalty (Alnaser et al., 2018; Pasha and Razashah, 2018). In the banking industry, by offering excellent service quality, customers' satisfaction can be improved which subsequently contributes to higher profitability (Nomran el al., 2018; Ali and Naeem, 2019). Minimizes customers' defection, enhances customers' loyalty, delivers chances for crossselling, encourages word-of-mouth suggestion and enhances corporate appearances are the outcomes of offering excellent service quality (Baumann et al., 2007; Moghavvemi et al., 2018; Shayestehfar and Yazdani, 2019). Hence to remain competitive (Iqbal et al., 2018),

\footnotetext{
JEL Classification — L6, L4, I43. KAUJIE Classification — L6, L4, I43

(C) Razali Haron, Noradilah Abdul Subar and Khairunisah Ibrahim. Published in Islamic Economic Studies. Published by Emerald Publishing Limited. This article is published under the Creative Commons Attribution (CC BY 4.0) license. Anyone may reproduce, distribute, translate and create derivative works of this article (for both commercial and non-commercial purposes), subject to full attribution to the original publication and authors. The full terms of this license may be seen at http:// creativecommons.org/licences/by/4.0/legalcode
} 
IES

28,1

4

all the dimensions of service quality must be attended to by Islamic banks (Moghavvemi et al., 2018). In addition, progress for the growth can be accelerated and long-term relationship with customers can be preserved by having greater service quality, which is particularly vital in the competitive business atmosphere of contemporary banking (Camarero, 2007).

In Malaysia, the development of the Islamic Financial Institutions (IFIs) was initiated with the setting up of the pilgrimage fund (Tabung Haji) in 1963 as the first Islamic savings institution. Few years following that, the enactment of the Islamic Banking Act in 1983 allowed the establishment of the first Islamic Bank in Malaysia, i.e. Bank Islam Malaysia Berhad. Later, with the liberalization of the IFIs, more institutions have been established. As for the nonbanking financial service institution, it started with the establishment of the first Takaful (Islamic insurance company) under the Takaful Act in 1984. The government of Malaysia has recognized the necessity to deal with a comprehensive diversity of products and services that serve to both Muslim and non-Muslim customers. In 1993, the government permitted commercial banks to operate Islamic windows where banks can operate their current infrastructure, staff and branch networks to provide Islamic financial scheme. Malaysia has been one of the leading countries to deal with the dual banking system where banks are providing Islamic as well as conventional banking products together. Nowadays, the financial institutions in Malaysia consist of commercial banks, Islamic banks, international Islamic banks, investment banks and other financial institutions. Currently, there are 16 licensed Islamic banks operating in Malaysia (Bank Negara Malaysia, 2018). According to the Islamic Financial Services Act (IFSA) 2013 (Act that repeals the Islamic Banking Act, 1983 and Takaful Act, 1984), Islamic banks and other IFIs that provide Islamic banking products and services are required to have Shariah Advisory Committee (SAC) to provide guidance to the institutions and to guarantee that the operations and actions of the institutions are in accordance with the Shari'ah principles. Islamic banking continued to expand at a much faster rate than the conventional banking in 2018, growing at $11 \%$ in contrast to the conventional banking which was at a 3.3\% growth. As at end-January 2019, Islamic financing comprised some $32 \%$ of the overall loans in the banking sector (The Star, 2019).

The objective of this study is to examine the dimension of service quality that affects customers' satisfaction and loyalty among customers of Islamic banks in Malaysia. Furthermore, this study will also examine the role of trust as a mediator between customers' satisfaction and loyalty. The rapid growth in banking sector in Malaysia made it important to understand and measure the service quality of Islamic Banks. According to Kashif et al. (2015), in their study on Islamic banking in the city of Kuching, Sarawak, Malaysia, PAKSERV model is a valid measurement to measure the service quality of Islamic banks. Alnaser et al. (2018) revealed that in the cultural context, PAKSERV model was the most appropriate scale and had predictive power of service quality in the banking industry of Palestine. The study of Kashif et al. (2015) however has its limitation in which respondents were focused only on postgraduate students and did not incorporate the role of trust in the relationship between customers' satisfaction and loyalty despite trust being one of the most important antecedents of collaborative relationships between customers and Islamic banks (Tabrani et al., 2018). Kashif et al. (2015) in their study recommended future research to engage on a wider range of samples to measure the service quality of Islamic banks. Given this gap, this study will focus on PAKSERV model in the context of Islamic banking in Malaysia by focusing on a broader range of respondents and the role of trust in the relationship between satisfaction and loyalty.

This study is organized into five sections. The first section explains the introduction about Islamic banking, and the second section deals with the related literature and the hypotheses development. The third presents the data and methodology, while the fourth discusses the empirical results. The last section concludes the whole study and presents managerial implications. 


\section{Literature review and hypotheses development}

\subsection{Service quality}

Parasuraman et al. (1988) perceived service quality as a global judgment, or attitude, relating to the superiority of the service according to the ten dimensions of service quality known as SERVQUAL model. The model is based on a perception that service quality originates from customers' judgment of predictable service and real service provided (Parasuraman et al., 1988). Literature shows a wide use of this model in a range of service industries to examine customers' response on service quality. The ten dimensions of service quality include reliability (dependability of service provider and accuracy of performance), responsiveness (promptness and helpfulness), competence (possession of the required skills and knowledge), access (approachability and ease of contact), courtesy (politeness, respect and friendliness of contact personnel), communication (keeping customers informed in language they can understand), credibility (trustworthiness, believability, honesty), security (the freedom from danger, risk or doubt), understanding (making the effort to understand the customer's needs) and tangibles (appearance of physical components).

Researchers have studied the concept of SERVQUAL model and adopted the measurement in examining different industries as claimed by Gaur and Agrawal (2006) and Saleem et al. (2016). However, the potential problems with the conceptual framework and empirical operationalization of SERVQUAL have been identified by researchers such as Arasli et al. (2005) and Njau et al. (2019). Despite its widespread use, SERVQUAL is being criticized specifically with regard to its reliability and validity, the use of different scores and the stability of its factor structure (Ladhari et al., 2011; Njau, 2019). SERVQUAL needs to be customized by adding items or changing the wording of the items (Njau, 2019). Furthermore, Lewis and Soureli (2006) argued that SERVQUAL is not a reliable model to employ in different cultural settings as customers' perceptions on quality vary and the extent to which cultures are individualistic and significant impacts customers' evaluation on service providers. Due to cultural and environmental differences, customers of services in different countries may have different perceptions of what service quality is (Guesalaga et al., 2016; Farah, 2017). Culture therefore strongly influences customers' expectations (Raajpoot, 2004; Alnaser et al., 2018).

Following this, Raajpoot (2004) engaged a mixed-method methodology (PAKSERV) in his study in Pakistan, and the results verified several SERVQUAL dimensions of service quality, i.e. tangibility and reliability. Nevertheless, other dimensions of SERVQUAL were substituted with four new dimensions, i.e. sincerity: the service personnel are genuine while providing the service; formality: the social distance is maintained and cultural rituals are performed well; personalization: the service provider pays individual attention and the service is highly customized and assurance: ability of service provider to provide confidence to guarantee safety, equal treatment and competence to perform professionally. Raajpoot (2004) tested the PAKSERV model on services industry where customers and employees directly communicate. Some studies have used PAKSERV and tested the service dimensions of the model and found it to be reliable in African banking business (Saunders, 2008) and in health care industry of Indonesia (Ratnawati and Kholis, 2019).

Kashif et al. (2015) used PAKSERV to investigate service quality of Islamic banks in Malaysia. In their study, personalization and sincerity significantly influence customers' satisfaction in Islamic banking services. However, reliability is found to be not significant in affecting customers' satisfaction on Islamic banking in Malaysia. Meanwhile, a study in Pakistan by Kashif et al. (2016) using PAKSERV has found that all dimensions have significant influence on customers' satisfaction in the Islamic banking of Pakistan. Karatape et al. (2005) and Alnaser et al. (2018) stated that service quality dimensions established in one culture might describe service quality in a different culture.

The conceptual model of the relationship between service quality and customers' satisfaction in this study is developed based on the literature. The service quality dimensions

Service quality of Islamic banks 
IES

28,1

discussed above are measured based on the PAKSERV model adapted from Rajpoot (2004), and the following hypotheses are proposed:

H1. Tangibility significantly influences and has positive effect on customers' satisfaction.

H2. Reliability significantly influences and has positive effect on customers' satisfaction.

H3. Assurance significantly influences and has positive effect on customers' satisfaction.

H4. Sincerity significantly influences and has positive effect on customers' satisfaction.

H5. Personalization significantly influences and has positive effect on customers' satisfaction.

H6. Formality significantly influences and has positive effect on customers' satisfaction.

\subsection{Customers' loyalty}

Loyalty refers to customers' long-term patronage for a specific bank over time (Ladhari et al., 2011). Meanwhile, Baumann et al. (2011) delineated customers' loyalty as a deeply held commitment to re-buy or re-patronize a preferred product consistently in future. Baumann et al. (2011) and Boonlertvanich (2019) clarified loyalty as a behavior and attitude of customers and indicate that the attitude and behavior can be evaluated to determine customers' loyalty. Literature shows that customers' satisfaction is a significant factor and is positively associated with customers' loyalty (Amin et al., 2013; Kashif et al., 2016; Ali and Naeem, 2019). These results are also in line with the studies conducted in the service setting of supermarket customers (Kitapci et al., 2013). The significant influence of customers' satisfaction on loyalty is also recorded in both Islamic and conventional banks by Ladhari et al. (2011); Saleem et al. (2016); Saleh et al. (2017) and Ali and Naeem (2019).

Kashif et al. (2016) in their study using PAKSERV on Islamic banks in Malaysia established that customers' satisfaction significantly influenced loyalty. Therefore, this study further validates that customers' satisfaction is a critical predictor of loyalty in Islamic banks, and the following hypothesis is proposed:

H7. Customers' satisfaction significantly influences and has positive effect on customers' loyalty.

\subsection{Trust}

Trust is a paradigm applied to characterize customers' struggles in reducing risk (Boonlertvanich, 2019). Sumaedi et al. (2015) stated that trust involves behavioral intention that signifies dependence of a customer on a service provider and it involves vulnerability and uncertainty on the role of the provider. Trust is also defined as the belief that a service provider's statement or promise is reliable and the provider will meet its commitments in the customer-service provider relationship. In relation to Islamic bank, trust means customer beliefs that a bank would perform its business in accordance with what is predicted by the customer of the bank. The degree of the customers' trust reflects the greater the customers' belief that Islamic banks will perform accordingly and vice versa (Sumaedi et al., 2015; Nomran and Haron, 2020). For this study, the term "Shari'ah" is used for items BT5 and BT6 in variable trust in order to capture customer's trust that the conducts of Islamic banks on all transactions strictly follow the Shariah rules. The BT5 questions whether the bank fulfills its obligations to the customer in accordance to Shariah rules as advised by the Shariah Supervisory Board of the bank and the BT6 questions whether the customer has confidence in the Islamic bank's services due to its fully Sharíah-compliance operations. Trust was 
recorded by Ratnawati and Kholis (2019) to have a positive effect on loyalty and may influence the overall satisfaction of existing customers and can attract interest of new customers. Hence, satisfaction has a positive effect on trust, and trust will eventually have a positive influence on loyalty to the bank (Boonlertvanich, 2019). If customers are satisfied with economic benefits that emerge from the customer-service provider relationship, they perceive the service provider as being trustworthy (Sumaedi et al., 2015). Satisfaction will influence the customer's confidence and his/her encouragement to contribute in collaborative business. Customer-provider commitment to the relationship is enriched by trust (Boonlertvanich, 2019). Thus, the following hypothesis is proposed:

H8. Customers' satisfaction significantly influences and has positive effect on trust.

Trust eventually grows to become loyalty and is a significant feature in customer-service provider relationship. Long-term relationship with customers is emphasized by trust and trustworthiness (Shainesh, 2012). In order to maintain and improve customers' loyalty, a bank must be trustworthy and committed to the services provided (Ndubisi et al., 2007; Nomran et al., 2018; Ali and Naeem, 2019). Therefore, the main feature in continuing a service relationship with one's bank is the act of trust (Lewis and Soureli, 2006; Ndubisi et al., 2007; Shainesh, 2012; Saleh et al., 2017). Trust is effective in expecting loyalty from customers and has deeper sentiment than satisfaction (Shainesh, 2012). Thus, a significant indicator in emerging customers' loyalty is attributed by trust (Castaneda, 2011; Shainesh, 2012). A satisfied customer may become a loyal customer when a customer has high level of trust (Dimitriadis et al., 2011). The higher the trust on a bank and the quality of the relationship, the more loyal its customers will be (Ndubisi et al., 2007; Ali and Naeem, 2019).

Therefore, banks should take more efforts to earn customers' trust (Ndubisi et al., 2007). This study hence will examine the relationship between customers' trust and loyalty and the role of trust as a mediator between customers' satisfaction and loyalty in Islamic banking services in Malaysia. The following hypothesis is proposed:

H9. Trust significantly influences and has positive effect on customers' loyalty.

According to Mutonyi et al. (2016), trust is a mediator between satisfaction and loyalty of producers in a fresh fruit supply chain. Trust may influence the social values between the producer and the buyer in the supply chain, which can eventually affect and improve producer's attachment in the relationship. This will boost the mutual benefit and strengthen the long-term engagement. Osman and Sentosa (2013) also disclosed that trust is a mediator between customers' satisfaction and loyalty in Malaysian tourism industry. Loyalty will be affected positively when a satisfied customer has trust on a firm (Kassim and Abdullah, 2010). Thus, trust is seen as a mediator between customers' satisfaction and loyalty. Therefore, this study hypothesizes the following:

H10. Trust mediates the relationship between customers' satisfaction and loyalty.

In this study, the conceptual model of PAKSERV in explaining the six dimensions of service quality and the role of trust as a mediator in the relationship between customers' satisfaction and loyalty is developed based on the literature as discussed above. Figure 1 illustrates the theoretical framework of the study following Rajpoot (2004); Ndubisi (2007); Kashif et al. (2015) and Kashif et al. (2016).

\section{Data and methodology}

The sample for this study is gathered from random convenience sampling comprising 401 customers of Islamic banks. In answering the questionnaires, respondents were ensured of confidentiality. Various control and filters questions were put in place to ensure the quality of
Service quality of Islamic banks 


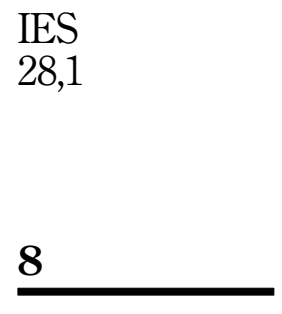

Figure 1.

Theoretical framework

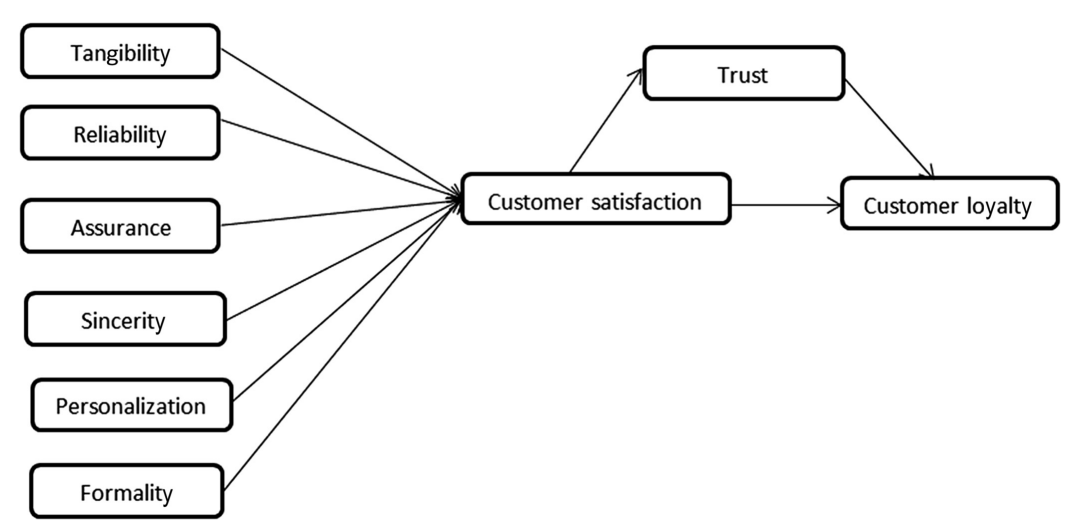

the survey. The purpose of the filter questions is to make sure that the respondents fit the three basic restrictions, i.e. minimum age of 18 years, holding account(s) with Islamic bank(s) and respondents agreed to participate in the survey. The survey was administered in English language. Every respondent was asked to choose one of the Islamic banks from those they might have transactions with as their main bank and to complete a questionnaire which would refer to their perceptions on the services provided by the bank.

The questionnaires were distributed using two approaches, i.e. face to face and online. Initially, the researchers visited and courteously approached the customers outside the Islamic bank counters, in order to distribute the questionnaires by hand. Selection of the respondents was from among the customers who visited the sampled Islamic banks during the banks' operating hours. The questionnaires were distributed during various working hours of the same day (morning and evening), along with the various days of the week, to lessen any potential bias due to high concentration of banks' customers during certain hours of the day or certain days of the week or month (Dusuki and Abdullah, 2007). The survey questionnaire was filled partly face to face and secondly, the remaining questionnaires were sent through online link which allowed the respondents to answer to the questions asked via online (Rehman, 2012). By using electronic device, researchers can reach a larger number of respondents and expedite the data collection phase.

The respondents were provided with a set of questionnaire consisting of the cover page and the contents which were written in English. The location of the survey was in Kuala Lumpur and Shah Alam (Selangor). The choices of the two cities were mainly due to their city capital status with substantial number of Islamic banks in the areas. The data were collected within the duration of three weeks in March 2019. A total of 410 out of 500 questionnaires were returned from respondents, and nine out of the returned questionnaires were considered as not useable because of unengaged responses. Thus, the overall response rate was $80.2 \%$, and data entry has been done for final analysis based on the final sample size of 401 respondents. The data were analyzed using two statistical programs, i.e. SPSS 23 and AMOS 23 software, by the application of the structural equation model (SEM) for hypotheses testing.

The questionnaire consists of five sections as follows: the first section states the demographic profile of respondents. The second and third sections consist of four questions each with six items to study customers' satisfaction and loyalty, adopted from the work of Nam et al. (2011). These measures have been used in the studies of customers' loyalty (Kashif et al., 2015; Kashif et al., 2016). Besides that, two items of customers' loyalty and customers' satisfaction were adopted from the work of Kaura et al. (2015). The fifth section contains six questions used to measure trust. Trust indicators were adapted from Ndubisi et al. (2007). 
A five-point Likert scale $(1=$ strongly disagree to $5=$ strongly agree) was used in the questionnaire to measure responses to the relevant questions. Bearing in mind the criticism of SERVQUAL model, the researchers employed the PAKSERV model that has been advocated for investigating service quality in the Asian setting (Raajpoot, 2004).

Raajpoot (2004) in his study on service quality in Pakistan provided evidence that culture (Hofstede, 2003) significantly influenced the dimensions of service quality. Following his finding, he concluded that due to the cultural differences between the western and Asian countries, the dimensions on service quality conducted in the United States (SERVQUAL), as proposed by Parasuranam et al. (1988), deem irrelevant in the context of Asian countries such as Pakistan. Raajpoot concluded two aspects from his studies as follows: first, culture causes the emergence of different dimensions of service quality and second, even if the same dimension is applicable, it can be interpreted differently between the two cultures. He provided three aspects of cultural differences that may influence the dimensions of service quality, which are collectivism, uncertainty avoidance and power distance. Collectivism is the degree which people in a culture prefer to act as group members rather than as individuals, and this is notable in Asian rather than the Western countries (Furrer et al., 2000). Uncertainty avoidance is defined as the degree to which people in a culture prefer structured over unstructured situations. Structured situations are those in which there are clear rules as to how one should behave. In the Asian culture, which is high in uncertainty avoidance, people are more rigid, while in the Western culture, which is low in uncertainty avoidance, people are more flexible (Redpath and Nielsen, 1997). Power distance is defined as the degree of inequality among people that a culture considers as normal. All societies are unequal, but some are more unequal than others (Hofstede, 2003). In cultures with high power distance like Pakistan, inequalities are expected and desired, with privileges and status symbols being expected and socially acceptable. Therefore, it is expected that customers in cultures with high power distance will place extreme importance on the recognition of their status in society and on receiving preferential service treatment. Based on these arguments on cultural differences, Raajpoot (2004) concluded two similar dimensions of service quality (reliability, tangibility) as SERVQUAL and discovered four new dimensions (assurance, sincerity, personalization, formality). Rajpoot (2004) termed these six dimensions of service quality as PAKSERV, which were later been adopted by many studies on service quality in Asian countries such as in Malaysia (Islamic banking) (Kashif et al., 2015), Thailand (conventional banking) (Boonlertvarich, 2019), Indonesia (health care industry) (Ratnawati and Kholis, 2019) and Pakistan (Islamic banking) (Kashif et al., 2016; Ali and Naim, 2019). This study employs PAKSERV due to the influence of culture on service dimensions in Asia as proposed by Raajpoot (2004) and the adoption of the model by many past studies in Asian service setting.

As PAKSERV is a model that explains service quality, the model therefore is appropriate to be applied on the studies of Islamic banking, being in a service industry. In order for Islamic banks to maintain and expand their customers' base, it is important for the bank to understand customers' perception toward the evaluation of banking services and to have a system by which customers' satisfaction is continuously measured and improved. Various studies such as Kashif et al. (2015); Kashif et al. (2016); Al-Naser et al. (2018) and Ali and Naim (2019) have employed PAKSERV to study the service quality of Islamic banks. Tabrani et al. (2018) suggest that one of the most important antecedents of collaborative relationships between customers and banks is trust. In the Islamic banking context, trust is referring to customers' belief that Islamic banking is operating in line with Sharíah rules and principles (Amin et al., 2013; Tabrani et al., 2018). Following this perspective, Sumaedi et al. (2015) explained that building trust in the Islamic banking is more challenging than in the conventional banks as interactions in Islamic banking are typically associated with religious issues and a set of beliefs. Therefore, trust has become one of the most important aspects for 
IES

28,1

customer-Islamic bank relationships (Amin et al., 2013; Ashraf et al., 2015; Sumaedi et al., 2015; Tabrani et al., 2018). This study therefore incorporates trust as an additional dimension to the existing dimensions of PAKSERV to make it relevant to the context of Islamic banking.

\section{Analysis and findings}

\subsection{Descriptive statistics}

Table 1 summarizes the demographics of the respondents of the study.

This study performs content validity in order to remove or revise questions that have not satisfied the research objectives (Alnaser et al., 2018). In order to guarantee the validity of the instrument, a thorough review of the existing literature is conducted, followed by a pilot test among experts on the subject, and then a confirmatory pilot test is undertaken involving a group of respondents (Kim et al., 2008; Alnaser et al., 2018). The pilot test among experts and professionals was performed to confirm that the scales measure what they were intended to measure (Haron and Ibrahim, 2016; Iqbal et al., 2018). Another pilot test was performed which did not involve any of the respondents of the previous pilot test. This process ensures that questions of the instrument are well specified and easily comprehended, in addition to avoiding any misinterpretations of their meaning among the respondents.

Unidimentionality analysis offers evidence that a concept that is not visible can be formed by combining different items (Iqbal et al., 2018). The two most common methods of assessing the level of unidimentionality of a factor are as follows: the exploratory factor analysis (EFA) and the confirmatory factor analysis (CFA). The main objective of the EFA is to summarise the information of a large group of variables into a smaller one by allocating them into distinct factors without significant loss of their information (Hair et al., 2006). The extraction of the factors was performed with the method of maximum likelihood and the Promax rotation. Furthermore, to test the reliability, sample adequacy and internal consistency of the scale items, Cronbach's alpha, KMO and Bartlett's tests were performed. Reliability analysis refers to the internal consistency of the factors (Chu and Murramann, 2006; Iqbal et al., 2018). Threshold value of reliability coefficient $(\alpha)$ for all scale items (mostly considered acceptable by researchers) should be 0.7 or above, and KMO should be greater than 0.50 (Hair et al., 2006). In addition, a factor loading of 0.50 for each item was considered as a threshold for retaining items to ensure a greater confidence (Hair et al., 2006). Often, variables with low communalities (less than 0.20 so that $80 \%$ are unique variables) are eliminated from the analysis as the aim of the factor analysis is to explain the variance through the common factors (Child, 2006).

The first stage of EFA was performed, and the variables T1, T3, P2 and F1 resulted in low communalities $(<0.2)$. As dimension reduction techniques seek to identify items with a shared variance, it is advisable to remove any item with communality score less than 0.2 (Child, 2006). Thus, all the low-factors communalities were removed from the variables in the EFA. The repetition of the EFA test must be done continuously until the overall data meet the minimum requirement. Thus, the second stage of EFA test was performed in which sampling adequacy (KMO) for overall construct obtained the result of 0.876 and Bartlett's test of sphericity is significant $(\phi=0.05)$, indicating factor analysis is good for further analysis. Table 2 shows the factor loadings of the items used and Cronbach's alpha for each factor. While examining the pattern matrix, it was found that all items loaded on their respective factors have good loadings $(>0.50)$ and communalities $(>0.2)$. The analysis showed that from the 35 items that were used, 9 factors are produced. The results of the analysis (Table 2) justify the use of the EFA as all the criteria were well exceeded.

For the next step, CFA was employed in this study to assess the measurement model and to test data quality (Gerbing and Anderson, 1988). The SEM is employed to assess the overall fit of the proposed model and to test the hypotheses. For assessment of CFA, various model fit 


\begin{tabular}{|c|c|c|c|}
\hline Demographic attributes & $n$ & $\%$ & Service quality \\
\hline \multicolumn{3}{|l|}{ Gender } & banks \\
\hline Male & 210 & 52.4 & \\
\hline Female & 191 & 47.6 & \\
\hline \multicolumn{4}{|l|}{ Marital Status } \\
\hline Single & 245 & 61.1 & 11 \\
\hline \multirow{2}{*}{$\begin{array}{l}\text { Married } \\
\text { Divorced }\end{array}$} & 148 & 36.9 & \\
\hline & 8 & 2 & \\
\hline \multicolumn{4}{|l|}{ Age } \\
\hline $18-24$ & 121 & 30.2 & \\
\hline $25-34$ & 152 & 37.9 & \\
\hline 35-44 & 71 & 17.7 & \\
\hline $45-54$ & 35 & 8.7 & \\
\hline 55 and above & 22 & 5.5 & \\
\hline \multicolumn{4}{|l|}{ Education level } \\
\hline SPM/STPM & 17 & 4.2 & \\
\hline College diploma/matriculation/ A-level & 85 & 21.2 & \\
\hline Bachelor degree & 211 & 52.6 & \\
\hline Master degree & 37 & 9.2 & \\
\hline $\mathrm{PhD}$ & 22 & 5.5 & \\
\hline Professional qualification & 29 & 7.2 & \\
\hline \multicolumn{4}{|l|}{ Occupation } \\
\hline Student & 97 & 24.2 & \\
\hline Government employee & 68 & 17 & \\
\hline Private employee & 201 & 50.1 & \\
\hline Businessman & 12 & 3 & \\
\hline Others & 23 & 5.7 & \\
\hline \multicolumn{4}{|l|}{ Monthly income } \\
\hline Less than RM1,000 & 105 & 26.2 & \\
\hline RM1,001-RM3,000 & 133 & 33.2 & \\
\hline RM3,001-RM5,000 & 87 & 21.7 & \\
\hline RM5,001-RM10,000 & 52 & 13 & \\
\hline RM10,001-RM20,000 & 14 & 3.5 & \\
\hline More than RM20,001 & 10 & 2.5 & \\
\hline \multicolumn{4}{|l|}{ The period of bank's customer relationship } \\
\hline Less than one year & 20 & 5 & \\
\hline One to two years & 60 & 15 & \\
\hline Two to three years & 81 & 20.2 & \\
\hline Above three years & 240 & 59.9 & \\
\hline \multicolumn{4}{|l|}{ Types of bank account } \\
\hline Current account & 86 & 21.4 & \\
\hline Saving account & 280 & 69.8 & \\
\hline Investment and financing account & 35 & 8.7 & Sample of respondents \\
\hline Total & 401 & 100 & of the study \\
\hline
\end{tabular}

indices for the measurement model were determined (Chau, 1997) as follows: CMIN/DF ( $<2$ is good and $2-5$ is acceptable); goodness of fit index (GFI $>0.90$ is good and $>0.80$ is acceptable); comparative fit index (CFI $>0.90)$; normed fit index (NFI $>0.90)$; root mean residual $(\mathrm{RMR}<0.10)$; root mean square error of approximation (RMSEA $<0.10)$ and adjusted goodness of fit index (AGFI $>0.80$ is good and $>0.70$ is acceptable). Factor loadings are 
IES

28,1

\section{2}

the standardized regression weights of the constructs with their items, the loadings above 0.70 are considered good and loadings above 0.60 can also be accepted (Hair et al., 2006). The model fit of the measurement model of this study is shown in Table 3 . The table shows that all the goodness of fit and badness of fit indices are in the acceptable range and supports EFA findings where all the standardized factor loadings emerged as fairly high. This shows that the measures display convergent validity (Gerbing and Anderson, 1988).

\begin{tabular}{|c|c|c|c|c|}
\hline & Conceptual factors & Items & Loadings & Cronbach's alpha \\
\hline & \multirow[t]{4}{*}{ Customer loyalty } & BL1 & 0.817 & \multirow[t]{4}{*}{0.885} \\
\hline & & BL2 & 0.858 & \\
\hline & & BL3 & 0.821 & \\
\hline & & BL4 & 0.697 & \\
\hline & \multirow[t]{4}{*}{ Customer satisfaction } & SB1 & 0.762 & \multirow[t]{4}{*}{0.895} \\
\hline & & SB2 & 0.893 & \\
\hline & & SB3 & 0.786 & \\
\hline & & SB4 & 0.747 & \\
\hline & \multirow[t]{3}{*}{ Tangibility } & $\mathrm{T} 2$ & 0.811 & \multirow[t]{3}{*}{0.848} \\
\hline & & $\mathrm{T} 4$ & 0.830 & \\
\hline & & $\mathrm{T} 5$ & 0.766 & \\
\hline & \multirow[t]{4}{*}{ Reliability } & $\mathrm{R} 1$ & 0.698 & \multirow[t]{4}{*}{0.852} \\
\hline & & $\mathrm{R} 2$ & 0.670 & \\
\hline & & R3 & 0.836 & \\
\hline & & $\mathrm{R} 4$ & 0.885 & \\
\hline & \multirow[t]{5}{*}{ Assurance } & $\mathrm{A} 1$ & 0.747 & \multirow[t]{5}{*}{0.842} \\
\hline & & $\mathrm{A} 2$ & 0.865 & \\
\hline & & $\mathrm{A} 3$ & 0.715 & \\
\hline & & A4 & 0.595 & \\
\hline & & A5 & 0.588 & \\
\hline & \multirow[t]{3}{*}{ Sincerity } & $\mathrm{S} 1$ & 0.841 & \multirow[t]{3}{*}{0.895} \\
\hline & & $\mathrm{S} 2$ & 0.847 & \\
\hline & & S3 & 0.889 & \\
\hline & \multirow[t]{3}{*}{ Personalization } & $\mathrm{P} 1$ & 0.595 & \multirow[t]{3}{*}{0.878} \\
\hline & & P3 & 0.960 & \\
\hline & & $\mathrm{P} 4$ & 0.927 & \\
\hline & \multirow[t]{3}{*}{ Formality } & $\mathrm{F} 2$ & 0.845 & \multirow[t]{3}{*}{0.834} \\
\hline & & F3 & 0.695 & \\
\hline & & $\mathrm{F} 4$ & 0.846 & \\
\hline & \multirow[t]{6}{*}{ Trust } & BT1 & 0.528 & \multirow[t]{6}{*}{0.889} \\
\hline Table 2. & & BT2 & 0.621 & \\
\hline Exploratory factor & & BT3 & 0.755 & \\
\hline analysis (EFA) and & & BT4 & 0.879 & \\
\hline eliability analysis & & BT5 & 0.908 & \\
\hline esults & & BT6 & 0.776 & \\
\hline
\end{tabular}

Overall fit of the model

Chi-square/degree of freedom $(x / d f)$

Table 3.

Normed fit index (NFI)

0.881

Model fit of the

Root mean square residual (RMR)

0.012 measurement model 
Based on the results of EFA, four items (out of 39) were deleted from the instrument because of low factor loadings. These items were T1, T3, P2 and F1. The results of CFA on the remaining 35 items showed a good fit of the data. In term of the path estimates (CFA loadings) of the measurement model, they were above 0.50; average variance extracted (AVE) above 0.50 and construct reliability above 0.70 indicate convergent validity and internal consistency. Thus, the final scale consists of 35 items (standardized confirmatory factor loadings are not reported here, available upon request). Figure 2 illustrates the measurement model.

Table 4 shows the discriminant validity of the construct. The square root of the AVE between each pair of factors was higher than the correlation estimated between factors, thus ratifying its discriminant validity (Hair et al., 2006).

\subsection{Hypotheses testing}

Finally, a SEM is constructed to assess the proposed structural model by employing the maximum likelihood estimation method. The proposed structural model is presented in Figure 3. Model fit of the structural model shown in Table 5 reveals that the model fits the data reasonably well.

The results summary provided in Figure 4 indicates an excellent fit of the PAKSERV model in the context of Islamic banking in Malaysia. The relationship between assurance and customer satisfaction is positive and significantly contributes to customers' satisfaction in Islamic banking, and H3 is thus supported $(0.380 ; p<0.01)$. This is followed by H5, which is also supported. The relationship between personalization and satisfaction is significant $(0.201 ; p<0.01)$, which is an important contributor toward satisfaction on services of Islamic banks. Then, the relationship between sincerity and customers' satisfaction appears to be significant $(0.185 ; p<0.01)$ where $\mathrm{H} 4$ is supported. The relationship between tangibility and customers' satisfaction is significant $(0.140 ; p<0.01)$, hence supporting H1. The relationship between formality and customers' satisfaction shows formality significantly influences customer satisfaction $(0.121 ; p<0.01)$, hence supporting H6. The relationship between reliability and customers' satisfaction on services of Islamic banks is also significant and positive $(0.120 ; p<0.01)$, supporting H2. Meanwhile, path coefficient of the relationship between customers' satisfaction and loyalty is $0.591(p<0.01)$. This indicates that customers' satisfaction is positively and significantly contributing toward customers' loyalty in services of Islamic banks. Thus, H7 is supported. The relationship between customers' satisfaction and trust is $0.605(p<0.01)$, showing that customers' satisfaction significantly influences trust, supporting H8. The relationship between trust and customers' loyalty is $0.187(p<0.01)$. The result demonstrates that trust significantly influences customers' loyalty, therefore supporting H9. The summary of the results is presented in Table 6.

The significance of trust, the standardized total and direct and indirect effect is determined by using the bias-corrected (BC) two-tailed percentile method with bootstrapping. Figure 5 describes the causal relationship between customers' satisfaction and customers' loyalty with the mediation of trust. The more detailed results of trust as a mediator are provided in Table 7 . The results of the direct and indirect path parameters reveal that trust acts as a partial mediator between customers' satisfaction and loyalty. The regression estimates and the $p$-values show that both the direct and indirect paths between customers' satisfaction and customers' loyalty are significant in the presence of trust as a mediator. H10 is therefore supported.

\section{Conclusion and managerial implication}

The results of this study confirm that all the six dimensions of PAKSERV model are reliable in the context of Islamic banking in Malaysia and each dimension has a significant positive relationship with the service quality of Islamic banks. The employment of PAKSERV is to 
IES

28,1

14

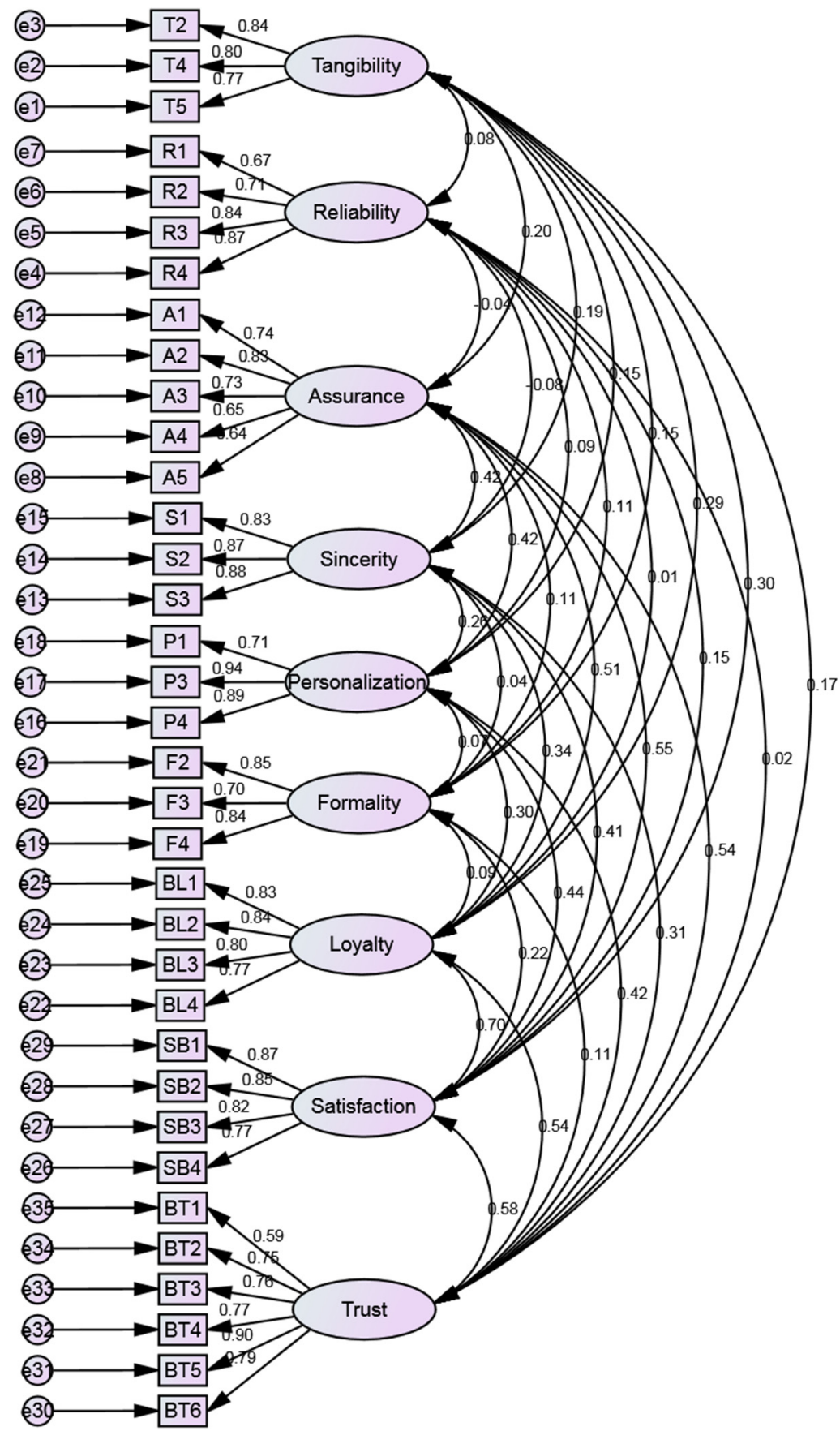

Figure 2.

The

measurement model 
exploit culturally sensitive service quality (Ganguli and Roy, 2011); hence it confirms that service quality and customers' satisfaction is a cultural phenomenon and is essential to be grounded in a local cultural context (Raajpoot, 2004; Malhotra et al., 2005; Moghavvemi et al., 2018).

In terms of key driver to the service quality of Islamic banks in Malaysia, assurance is the most important driver to service quality, followed by personalization, sincerity, tangibility, formality and reliability. This reveals that customers of Islamic banks chose banks that provide financially safe investment, have appropriate knowledge about products and services and practice courtesy in delivering services. Additionally, customers are also particular on equal service offered to all customers and have competent employees to perform services professionally. Consequently, excellent service quality asks staff to be polite with customers, to be competent, provides effort on delivering appropriate financial advice, and customers to have easy access to their account information. Then, customers primarily focused on the personalization and sincerity dimensions. As Asian culture is attributed to a greater acknowledgment of social status and power distance (Raajpoot, 2004), paying attention on personalization is understandable. This indicates the influences of social status in describing service quality, even in the context of Islamic banking, hence having implication on Islamic bank marketers (Kashif et al., 2016; Alnaser et al., 2018). Given the higher customer focus toward personalization, the bank staff must provide individual attention on services offered by Islamic banks. This way, Islamic banks can attract more customers. Imrie et al. (2013) suggested that highly customized solutions to customers have been found to help marketers in attracting more customers.

It is an established argument that people in collectivist cultures are less tolerant to risks connected with business, and this is applicable even in consumer spending on various goods and services (Hofstede, 2003). A high score on uncertainty avoidance advocates the importance of a sincere advice which is expected by customers as part of a service quality. This entails that such customers need a higher level of sincere advice that is personal in nature, in order to minimize his/her perceptions of risk associated with a service encounter (Kashif et al., 2015). As Asians are not prepared to take higher risks in many decisions, it can slow down the service consumption progression in such societies (Lee et al., 2007). The service consumption risk in Asian societies can be minimized through sincerity during service provision. This is where the frontline staff is recommended to earn a reputation of providing proactive, well-mannered and a personalized advice to the customers (Raajpoot, 2004; Eze et al., 2019). Thus, the high score on sincerity dimension explains the significance of a personal and highly sincere advice predicted by Asian customers from bank staff during service encounters. These outcomes also emphasize the significance of national culture comprehending the perceived service quality (Hofstede, 2003). It also has a special implication

\begin{tabular}{lccccccccr}
\hline & SB & R & T & A & S & P & F & BL & BT \\
\hline Satisfaction (SB) & 0.827 & & & & & & & & \\
Reliability (R) & 0.145 & 0.776 & & & & & & & \\
Tangibility (T) & 0.30 & 0.077 & 0.807 & & & & & & \\
Assurance (A) & 0.553 & -0.037 & 0.204 & 0.720 & & & & & \\
Sincerity (S) & 0.406 & -0.082 & 0.19 & 0.42 & 0.86 & & & & \\
Personalization (P) & 0.438 & 0.088 & 0.149 & 0.425 & 0.256 & 0.852 & & & \\
Formality (F) & 0.223 & 0.109 & 0.151 & 0.106 & 0.035 & 0.066 & 0.797 & & \\
Loyalty (BL) & 0.696 & 0.01 & 0.286 & 0.509 & 0.336 & 0.302 & 0.087 & 0.811 & \\
Trust (BT) & 0.585 & 0.025 & 0.17 & 0.542 & 0.308 & 0.421 & 0.109 & 0.545 & 0.764
\end{tabular}

Note(s): Diagonals represent the square root of the AVE, while the off diagonals represent the correlations

Service quality of Islamic banks

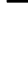


IES

28,1

16

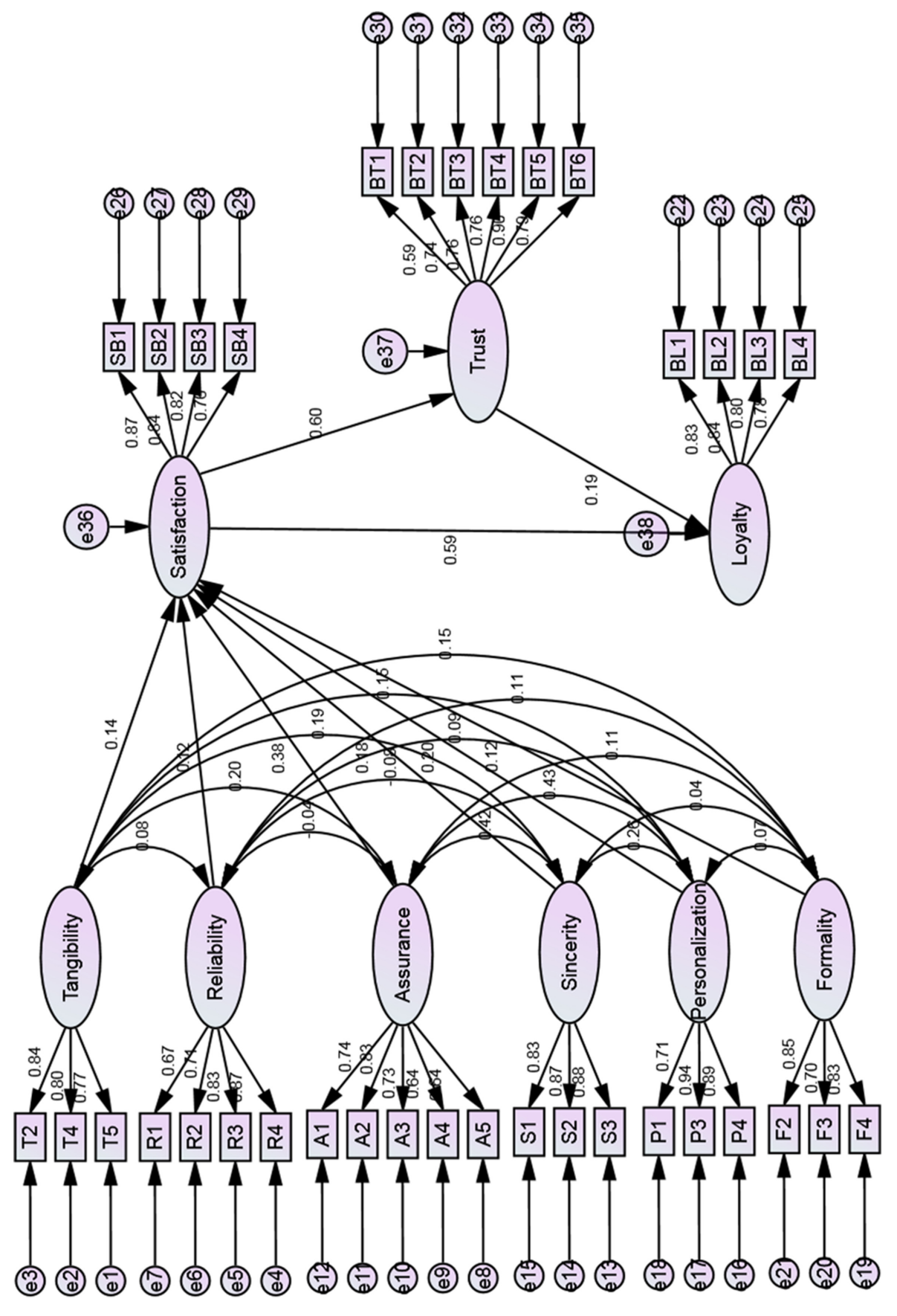

Figure 3.

The structural
equation model (SEM) 
for Islamic bank marketers as the sincere advice can minimize the risks related to banking transactions. It can also result in customers switching from conventional banks to benefit the services of Islamic banks (Kashif et al., 2016; Saleh et al., 2017). Furthermore, the rapid development and competition of banking services have made it important for banks to measure the service quality (Alnaser et al., 2018). The outcomes specified that the PAKSERV dimensions of assurance, personalization and sincerity are found to be critical for Islamic banks in constructing and executing service quality programs to customers.

Interestingly, the formality dimension though being important is low-ranked based on the results of this study. This contradicts with the work of Raajpoot (2004) but nevertheless supports the findings of Saunders (2008) and Kashif et al. (2016) who replicated the

Service quality of Islamic banks

Overallfit of the model

Chi-square/degree of freedom $(x / d f)$
Table 5.

Model fit of structural model

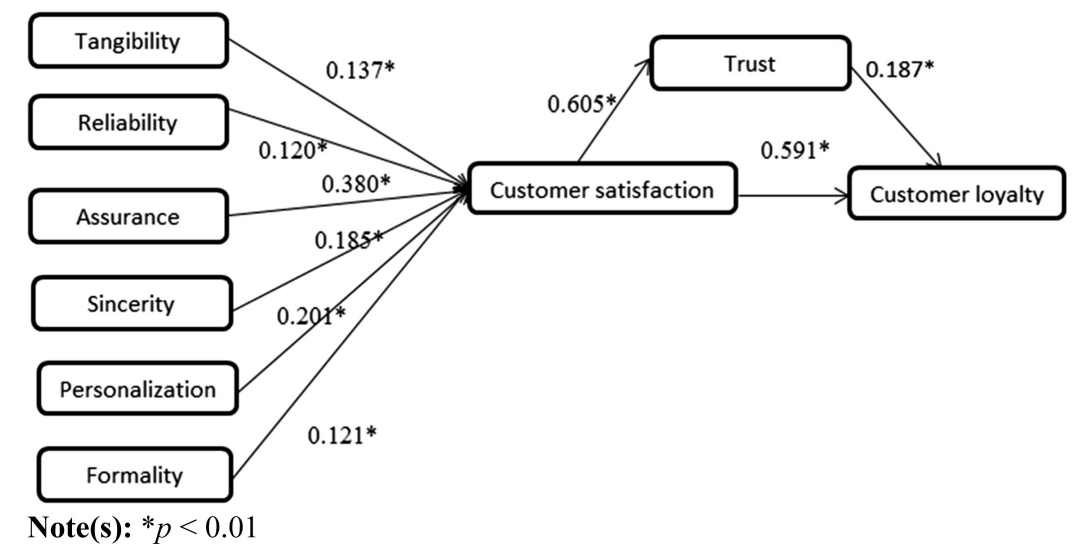

Figure 4. Result summary

\begin{tabular}{lcccc}
\hline Hypothesized path & Standardized coefficients & $t$-value & $p$-value & Hypotheses \\
\hline H1.SB $\leftarrow \mathrm{T}$ & 0.137 & 2.904 & 0.004 & Supported \\
$\mathrm{H} 2 . \mathrm{SB} \leftarrow \mathrm{R}$ & 0.120 & 2.668 & 0.008 & Supported \\
$\mathrm{H} 3 . \mathrm{SB} \leftarrow \mathrm{A}$ & 0.380 & 6.226 & 0.003 & Supported \\
$\mathrm{H} 4 . \mathrm{SB} \leftarrow \mathrm{S}$ & 0.185 & 3.692 & 0.006 & Supported \\
$\mathrm{H} 5 . \mathrm{SB} \leftarrow \mathrm{P}$ & 0.201 & 4.079 & 0.001 & Supported \\
$\mathrm{H} 6 . \mathrm{SB} \leftarrow \mathrm{F}$ & 0.121 & 2.642 & 0.005 & Supported \\
$\mathrm{H} 7 . \mathrm{BL} \leftarrow \mathrm{SB}$ & 0.591 & 9.685 & 0.002 & Supported \\
$\mathrm{H} 8 . \mathrm{BT} \leftarrow \mathrm{SB}$ & 0.605 & 9.330 & 0.004 & Supported \\
H9.BL $\leftarrow \mathrm{BT}$ & 0.187 & 3.256 & 0.001 & Supported
\end{tabular}

Note(s): $\mathrm{SB}=$ customer satisfaction; $\mathrm{T}=$ Tangibility; $\mathrm{R}=$ Reliability; $\mathrm{A}=$ Assurance; $\mathrm{S}=$ Sincerity; $\mathrm{P}=$ Personalization; $\mathrm{F}=$ Formality; $\mathrm{BL}=$ Customer loyalty; $\mathrm{BT}=$ Customer trust

Table 6.

Results of the structural model 
IES

28,1

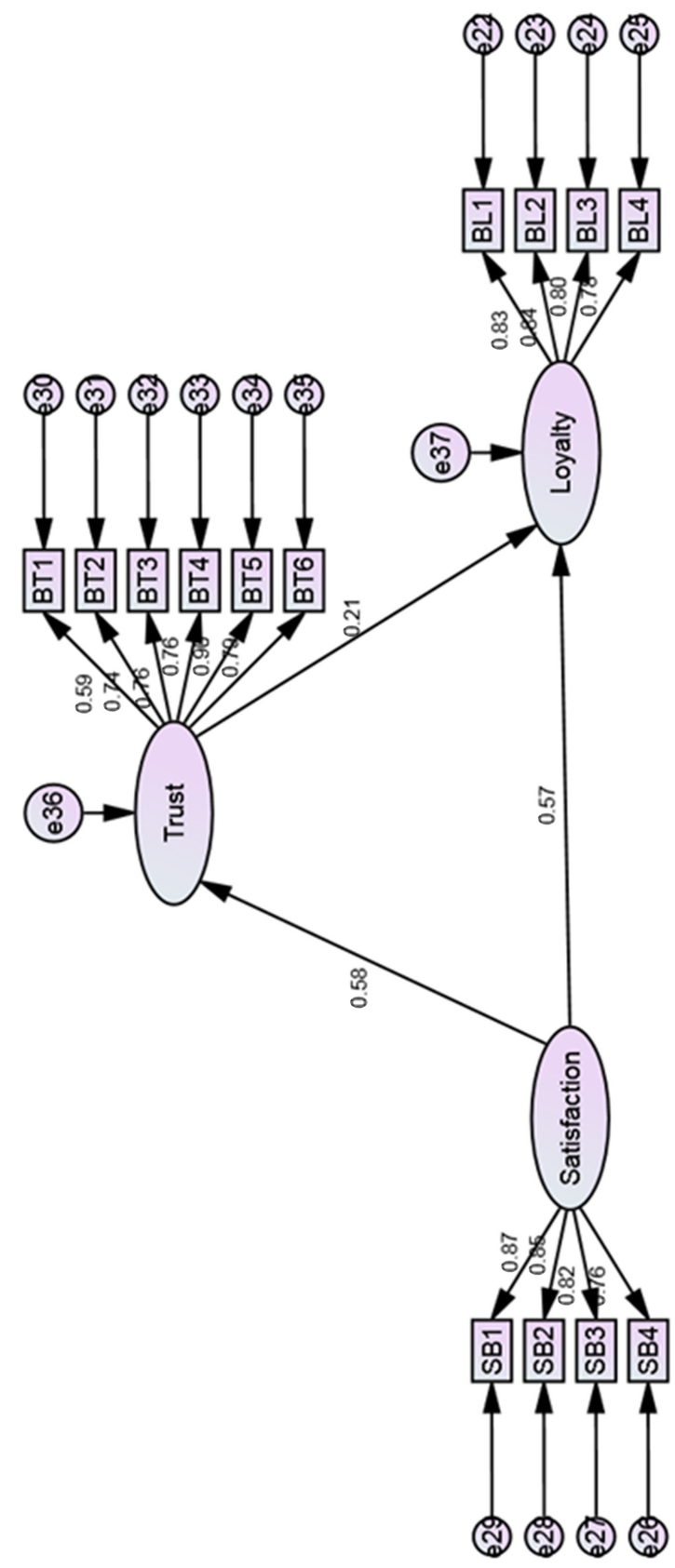

Figure 5

Mediation model with

trust as a mediator 


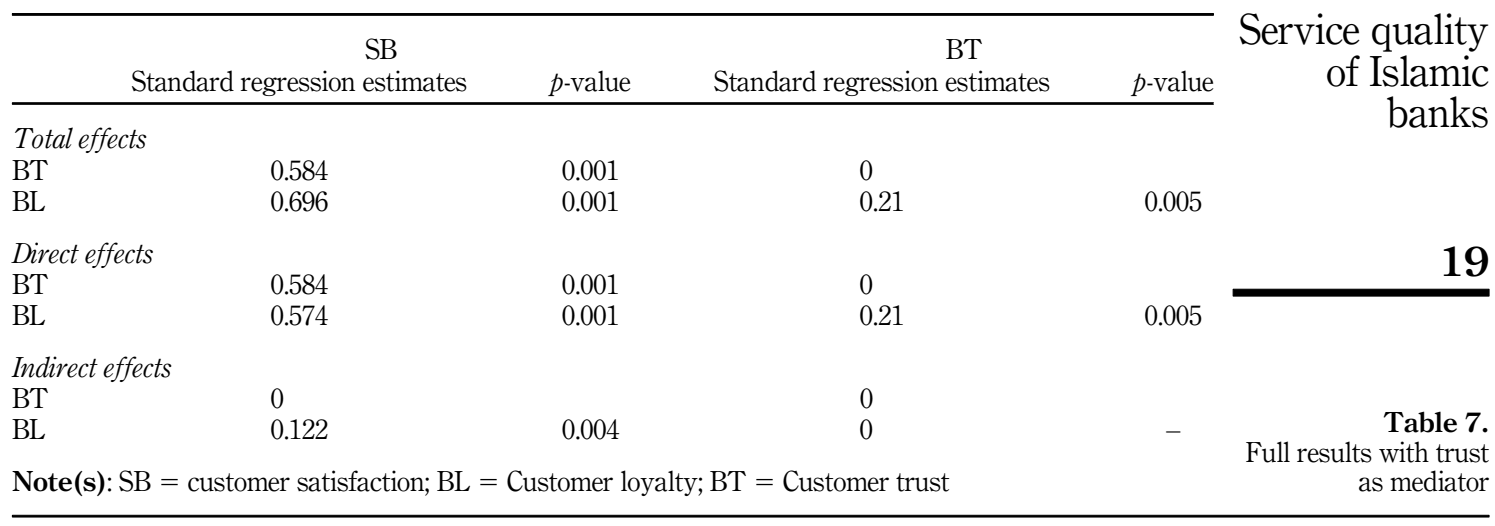

PAKSERV model in African and Pakistan banking context and found formality a less desirable dimension. Therefore, a slighter emphasis on formality and better concentration on personalization and sincerity are reasonable (Kashif et al., 2016). In this study, reliability recorded the lowest coefficient of service quality despite being significantly and positively related to customers' satisfaction on the service quality of Islamic banks in Malaysia. The results of this study support the claims of Malhotra et al. (2005) and Alnaser et al. (2018) that perceptions of service quality differ by nationality due to the differences in economic, social and cultural atmospheres.

It has been recorded that customers' satisfaction is a strong predictor of customers' loyalty in the context of Islamic banking in Malaysia (Saleh et al., 2017). The result of the current study strongly supports this relationship. These findings are in line with the previous studies that signal the importance of achieving service quality in order to ensure customers' loyalty in service settings (Baumann et al, 2011). The results supported all hypotheses proposed in this study. Through the results, it has been found that a PAKSERV-based customers' satisfaction leads to customers' loyalty in Islamic banks, which is in line with the studies of Kashif et al. (2015); Kashif et al. (2016) and Alnaser et al. (2018). These results are also in line with the studies conducted in other service settings (Amin et al., 2013; Kitapci et al., 2013; Saleh et al., 2017). Although Islamic banking customers are satisfied with the overall service quality provided by Islamic banks, it is not guaranteed that their customers will not switch to other banks. Therefore, Islamic banks need to continue improving the relationship between bank and customers by increasing customers' trust toward the services provided (Saleh et al., 2017; Nomran et al., 2018).

In the context of Islamic banking in Malaysia, customers' trust in Islamic banks may be linked to customers' perception on the products and services (Nomran et al., 2018). This study also provides survey evidence that satisfaction has a positive effect on trust and trust eventually has a positive influence on loyalty to the bank. The positive sign of the estimates shows that the greater the level of customers' satisfaction, the higher the level of customers' trust and the greater the level of trust, the higher the level of customers' loyalty. All elements of the research propositions are thus firmly supported. This study also reveals that trust acts as a partial mediator between customers' satisfaction and customers' loyalty. Trust may influence the customers' decisions toward building the long-term relationship with Islamic banks, which in turn can result in satisfied customers having greater trust on the banks, and this will enhance the long-term relationship even further.

The results of this study contribute to the literature and the practices of service quality in Islamic banking. Islamic banks in Malaysia can achieve numerous benefits by advancing the provisions of service quality as desired by customers. This study found all the six dimensions 
IES

28,1

of PAKSERV model have been reliable in the context of Islamic banking in Malaysia. The results of this study uphold the idea that service quality and customers' satisfaction is a cultural occurrence and backed by local cultural background. Banks should continue gaining customers' trust and satisfaction. This can be achieved by showing concern on the security of transactions, delivering quality services, showing respect for customers through frontline staff, fulfilling commitments and performing to develop customers' confidence toward the banks and its services. The findings of this study therefore can be used as a framework for other Islamic financial institutions (IFIs) in improving services to its customers.

\section{References}

Ali, S.F. and Naeem, M. (2019), "Does service quality increase the level of banks performance. Comparative analysis between conventional and Islamic banks", Journal of Management Development, Vol. 38 No. 6, pp. 442-454.

Alnaser, F.M.I., Abd Ghani, M. and Rahi, S. (2018), "Service quality in Islamic banks: the role of PAKSERV model, customer satisfaction and customer loyalty", Accounting, Vol. 4 No. 2, pp. 63-72.

Amin, M., Isa, Z. and Fontaine, R. (2013), "Islamic banks: contrasting the drivers of customer satisfaction on image, trust, and loyalty of Muslim and non-Muslim customers in Malaysia", International Journal of Bank Marketing, Vol. 31 No. 2, pp. 79-97.

Ashraf, S., Robson, J. and Sekhon, Y. (2015), "Consumer trust and confidence in the compliance of Islamic banks", Journal of Financial Services Marketing, Vol. 20 No. 2, pp. 133-144.

Arasli, H., Mehtap-Smadi, S. and Katircioglu, S.T. (2005), "Customer service quality in the Greek Cypriot banking industry", Managing Service Quality, Vol. 15 No. 1, pp. 41-56.

Bank Negara Malaysia (2018), List of Licensed Financial Institutions, Bank Negara Malaysia, Kuala Lumpur.

Baumann, C., Burton, S., Elliott, G. and Kehr, H.M. (2007), "Prediction of attitude and behavioural intentions in retail banking", International Journal of Bank Marketing, Vol. 25 No. 2, pp. 102-116.

Baumann, C., Elliott, G. and Hamin, H. (2011), "Modelling customer loyalty in financial services: a hybrid of formative and reflective constructs", International Journal of Bank Marketing, Vol. 29 No. 3, pp. 247-267.

Boonlertvanich, K. (2019), "Service quality, satisfaction, trust, and loyalty: the moderating role of main-bank and wealth status", International Journal of Bank Marketing, Vol. 37 No. 1, pp. 278-302.

Calabrese, F.A. (2005), "The early pathways: theory to practice - a continuum”, in Stankosky, M. (Ed.), Creating the Discipline of Knowledge Management, Elsevier, New York, NY, pp. 15-20.

Camarero, C. (2007), "Relationship orientation or service quality? What is the trigger of performance in financial and insurance services?", International Journal of Bank Marketing, Vol. 25 No. 6, pp. 406-426.

Castaneda, J.S. (2011), "Relationship between customer satisfaction and loyalty on the internet", Journal of Business and Psychology, Vol. 26, No.1, pp. 1371-1383.

Chau, P. (1997), "Reexamining a model for evaluating information center success using a structural equation modeling approach", Decision Sciences, Vol. 28, No.2, pp. 309-334.

Child, D. (2006), The Essentials of Factor Analysis, Continuum International Publishing, New York.

Chu, K.H. and Murramann, S.K. (2006), "Development and validation of the hospitality emotional labor scale”, Tourism Management, Vol. 27 No. 6, pp. 1181-1191.

Dimitriadis, S., Kouremenos, A. and Kyrezis, N. (2011), "Trust-based segmentation preliminary evidence from technology-enabled bank channels", International Journal of Bank Marketing, Vol. 29 No. 1, pp. 5-31.

Dusuki, A.W. and Abdullah, N.I. (2007), "Why do Malaysian customers patronize Islamic banks?”, International Journal of Bank Marketing, Vol. 25 No. 3, pp. 142-160. 
Eze, B.U., Adelekan, A.S., Ojo, O.J. and Erigbe, P.A., (2019), "Emotional intelligence and job performance of frontline employees of selected microfinance banks in Lagos, Nigeria", Management Science Review, Vol. 10 No. 1, pp. 99-106.

Farah, M.F. (2017), "Consumers' switching motivations and intention in the case of bank mergers: a cross-cultural study", International Journal of Bank Marketing, Vol. 35 No. 2, pp. 254-274.

Furrer, O., Liu, B. and Sudharshan, D. (2000), "The relationships between culture and service quality perceptions - basis for cross-cultural market segmentation and resource allocation", Journal of Service Research, Vol. 2 No. 4, pp. 355-371.

Ganguli, S. and Roy, S.K. (2011), "Generic technology-based service quality dimensions in banking: impact on customer satisfaction and loyalty", International Journal of Bank Marketing, Vol. 29 No. 2, pp. 168-189.

Gaur, S.S. and Agrawal, R. (2006), "Service quality measurement in retail store context: a review of advances made using SERVQUAL and RSQS", The Marketing Review, Vol. 6 No. 4, pp. 317-330.

Gerbing, D.W. and Anderson, J.C. (1988), "An updated paradigm for scale development incorporating unidimensionality and its assessment", Journal of Marketing Research, Vol. 25 No. 2, pp. 186-192.

Guesalaga, R., Pierce, M. and Scaraboto, D. (2016), "Cultural influences on expectations and evaluations of service quality in emerging markets", International Marketing Review, Vol. 33 No. 1, pp. 88-111.

Hair, J.E., Black, W.C., Babin, B.J., Anderson, R.E. and Tatham, R.L. (2006), Multivariate Data Analysis, Pearson Prentice-Hall. Upper Saddle River, NJ.

Haron, R. and Ibrahim, K. (2016), "Islamic financing in mitigating access to financing problems of SMEs in Malaysia: a survey analysis", Intellectual Discours, (Special Issue 2016), pp. 387-408.

Hofstede, G.H. (2003), Cultures and Organizations - Software of the Mind, Profile Books, London.

Imrie, B.C., Cadogan, J.W. and McNaughton, R. (2013), "The service quality construct on a global stage”, Managing Service Quality: An International Journal, Vol. 12 No. 1, pp. 10-18.

Iqbal, M., Nisha, N. and Rashid, M. (2018), "Bank selection criteria and satisfaction of retail customers of Islamic banks in Bangladesh”, International of Bank Marketing, Vol. 36 No. 5, pp. 931-946.

Karatape, O., Yavas, U. and Babakus, E. (2005), "Measuring service quality of banks: scale development and validation", Journal of Retailing and Consumer Services, Vol. 12 No. 5, pp. 373-383.

Kashif, M., Wan Shukran, S.S., Rehman, M.A. and Sarifuddin, S. (2015), "Customer satisfaction and loyalty in Malaysian Islamic banks: a PAKSERV investigation", International Journal of Bank Marketing, Vol. 33 No. 1, pp. 23-40.

Kashif, M., Abdur Rehman, M. and Pileliene, L. (2016), "Customer perceived service quality and loyalty in Islamic banks: a collectivist cultural perspective”, The TQM Journal, Vol. 28 No. 1, pp. 62-78.

Kassim, N. and Abdullah, N. (2010), "The effect of perceived service dimension on customer satisfaction, trust, loyalty in e-commerce settings: a cross-cultural analysis", Asia Pacific Journal of Marketing and Logistics, Vol. 22 No. 3, pp. 351-371.

Kaura, V., Durga Prasad, C.S. and Sharma, S. (2015), "Service quality, service convenience, price and fairness, customer loyalty, and the mediating role of customer satisfaction", International Journal of Bank Marketing, Vol. 33 No. 4, pp. 404-422.

Kim, D.J., Ferrin, D.L. and Rao, H.R. (2008), "A trust-based consumer decision making model in electronic commerce: the role of trust, perceived risk, and their antecedents", Decision Support Systems, Vol. 44 No. 2, pp. 544-564.

Kitapci, O., Dortyol, I.T., Yaman, Z. and Gulmez, M. (2013), "The paths from service quality dimensions to customer loyalty: an application on supermarket customers", Management Research Review, Vol. 36 No. 3, pp. 239-255. 
IES

28,1

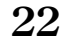

Ladhari, R., Ladhari, I. and Morales, M. (2011), "Bank service quality: comparing Canadian and Tunisian customer perceptions", International Journal of Bank Marketing, Vol. 29 No. 3, pp. 224-246.

Lee, J.A., Garbarino, E. and Lerman, D. (2007), "How cultural differences in uncertainty avoidance affect product perceptions", International Marketing Review, Vol. 24 No. 3, pp. 330-349.

Lewis, B.R. and Soureli, M. (2006), "The antecedents of consumer loyalty in retail banking”, Journal of Consumer Behaviour, Vol. 5 No. 1, pp. 15-31.

Malhotra, N.K., Ulgado, F.M., Agarwal, J., Shainesh, G. and Wu, L. (2005), "Dimensions of service quality in developed and developing economies: multi-country cross-cultural comparisons", International Marketing Review, Vol. 22 No. 3, pp. 256-278.

Moghavvemi, S., Lee, S.T. and Lee, S.P. (2018). "Perceived overall service quality and customer satisfaction: a comparative analysis between local and foreign banks in Malaysia", International Journal of Bank Marketing, Vol. 36 No. 5, pp. 908-930.

Mutonyi, S., Beukel, K., Gyau, A. and Hjortsø, C.N. (2016), "Price satisfaction and producer loyalty: the role of mediators in business to business relationships in Kenyan mango supply chain”, British Food Journal, Vol. 118 No. 5, pp. 1067-1084.

Nam, J., Ekinci, Y. and Whyatt, G. (2011), "Brand equity, brand loyalty and consumer satisfaction”, Annals of Tourism Research, Vol. 38 No. 3, pp. 1009-1030.

Ndubisi, N.O., Wah, C.K. and Ndubisi, G.C. (2007), "Supplier-customer relationship management and customer loyalty: the banking industry perspective", Journal of Enterprise Information Management, Vol. 20 No. 2, pp. 222-236.

Njau, F.W., Mutungi, M.M. and Mutinda, R. (2019), "An integrated SERVQUAL and gap model in evaluating customer satisfaction in budget hotels in Nairobi City County, Kenya”, International Journal of Current Aspects, Vol. 3 No. II, pp. 41-70.

Nomran, N. and Haron, R. (2020), "Shari'ah governance for Islamic banking: evidence from diverse regulatory environments", in Rafay, A. (Ed.), Growth and Emerging Prospects of International Islamic Banking, IGI Global, Hershey PA, pp. 213-244.

Nomran, N., Haron, R. and Hassan, R. (2018), "Shari'ah supervisory board characteristics effects on Islamic banks' performance: evidence from Malaysia”, International Journal of Bank Marketing, Vol. 36 No. 2, pp. 290-304.

Osman, Z. and Sentosa, I. (2013), "A study of mediating effect of trust on customer satisfaction and customer loyalty relationship in Malaysian rural tourism", European Journal of Tourism Research, Vol. 6 No. 2, pp. 192-206.

Parasuraman, A., Zeithaml, V.A. and Berry, L.L. (1988), "SERVQUAL: a multiple-item scale for measuring consumer perceptions of service quality", Journal of Retailing, Vol. 64 No. 1, pp. $12-40$.

Pasha, M.A. and Razashah, M. (2018), "Impact of service quality on customer satisfaction: an empirical study in selected public and private sector banks", Journal of Arts, Science and Commerce, Vol. IX No. 1, pp. 64-73.

Raajpoot, N. (2004), "Reconceptualizing service encounter quality in non-western context", Journal of Service Research, Vol. 7 No. 2, pp. 181-201.

Ratnawati, A. and Kholis, N. (2019), "Measuring the service quality of BPJS health in Indonesia: a sharia perspective", Journal of Islamic Marketing, Vol. 11 No. 4, pp. 1-23.

Redpath, L. and Nielsen, M.O. (1997), "A comparison of native culture, non-native culture and new management ideology", Canadian Journal of Administrative Sciences, Vol. 11 No. 4, pp. 1-23.

Rehman, A. (2012), "Customer satisfaction and service quality in Islamic banking: a comparative study in Pakistan, United Arab Emirates and United Kingdom", Qualitative Research in Financial Markets, Vol. 4 No. 2-3, pp. 165-175. 
Saleem, M.A., Zahra, S., Ahmad, R. and Ismail, H. (2016), "Predictors of customer loyalty in the Pakistani banking industry: a moderated-mediation study", International Journal of Bank Marketing, Vol. 34 No. 3, pp. 411-430.

Saleh, M.A., Quazi, A., Keating, B. and Gaur, S.S. (2017), "Quality and image of banking services: a comparative study of conventional and Islamic banks", International Journal of Bank Marketing, Vol. 35 No. 6, pp. 878-902.

Saunders, S.G. (2008), "Measuring and applying the PAKSERV service quality construct: evidence from a South African cultural context”, Managing Service Quality, Vol. 8 No. 5, pp. 442-456.

Shainesh, G. (2012), "Effects of trustworthiness and trust on loyalty intentions: validating a parsimonious model in banking", International Journal of Bank Marketing, Vol. 30 No. 4, pp. 267-279.

Shayestehfar, R. and Yazdani, B. (2019), "Bank service quality. A comparison of service quality between BSI branches in Isfahan and Dubai", The TQM Journal, Vol. 31 No. 1, pp. 28-51.

Sumaedi, S., Juniarti, R.P. and Bakti, I.G.M.Y. (2015), "Understanding trust and commitment of individual saving customers in Islamic banking: the role of ego involvement", Journal of Islamic Marketing, Vol. 6 No. 3, pp. 406-428.

Tabrani, M., Amin, M. and Nizam, A. (2018), "Trust, commitment, customer intimacy and customer loyalty in Islamic banking relationships", International Journal of Bank Marketing, Vol. 36 No. 5 , pp. 823-848.

The Star (2019), "Islamic banks still anchoring growth of banking sector", available at: https:// www.thestar.com.my/business/business-news/2019/03/27/islamic-banks-still-anchoring-growthof-banking-sector.

\section{Corresponding author}

Razali Haron can be contacted at: hrazali@iium.edu.my
Service quality of Islamic banks

For instructions on how to order reprints of this article, please visit our website:

www.emeraldgrouppublishing.com/licensing/reprints.htm

Or contact us for further details: permissions@emeraldinsight.com 